\title{
The Potential of Digital Application Development for Learning Local Language Paser
}

\author{
Angga Saputra ${ }^{1, *}$ Intan Rizky Mutiaz ${ }^{2}$
}

\author{
${ }^{1}$ Institut Teknologi Bandung, Indonesia \\ ${ }^{2}$ Institut Teknologi Bandung, Indonesia \\ *Corresponding author.Email: anggapolnes@gmail.com
}

\begin{abstract}
This article considers the aspect of application needs as a medium for learning the language of the Paser tribe. Currently, the speaking of the Paser language has decreased because many young people are embarrassed and do not regularly use the Paser language, especially in public places. One of the local government's efforts to preserve the paser language is through primary school education. However, there are obstacles faced by teachers in teaching, the main obstacle is still the absence of paser language textbooks, the second obstacle is direct teaching methods both oral and written are still difficult to understand by students. So a solution is needed for these problems at this time, digital learning methods are becoming very popular because they can provide information visually and sound so that they are considered able to improve learning outcomes. Based on this, this study looks at the potential use of digital applications as a means of learning the Paser language. The method used in this study is to compare the use of three digital media (illustration books, animations, and games) as language learning media. The author explains how each learning media can affect learning outcomes. The result is that digital media can increase motivation, interest, and audience interaction in learning. The more visual and audio elements provided, the better the learning success rate.
\end{abstract}

Keywords: Local Language, Digital Learning, User Engagement, Motivation to Learn

\section{INTRODUCTION}

Indonesia is a multicultural country that has many tribes, cultures, traditions, customs, and languages. The Paser tribe is one of the tribes in Indonesia. Most of the Paser indigenous people live and settle in Paser Regency, East Kalimantan Province, Indonesia [1]. They have their own language that is used for traditional rituals, music, regional dances, and so on. However, many young people do not use Paser language frequently as a part of communication. The research that is conducted by the local government, found the number of Paser Language native speakers is declining. This was caused by several factors. The main factor is that they are not confident in using the Paser language, especially in public places, and prefer to use Indonesian or slang [2]. This condition can give many drawbacks to the Paser community. It forces the local government to find the solution to preserve Paser language.
One of the roles of the local government in preserving the local Paser language is to include the Paser language in elementary school education as one of the local content subjects starting from class II to class $\mathrm{V}$ [3]. Recognition and preservation of language must start early, especially at the golden age because children will more easily remember every conversation of a language. The impact is very good if applied to pre-school because children will master the language faster [4]. However, the reality shows big problem. Many challenges must be faced in teaching the Paser language. Mr. Ahmad Effendy, a Paser language teacher, said that the main challenge in teaching Paser language is there are no Paser language textbooks published by the local government. The second challenge is the lack of teachers ability who can teach the Paser language. It makes Paser language subject is still not evenly distributed in every school. It is because, only a few teachers who are indigenous Paser people who teach the Paser language, most of the teachers are 
immigrants from areas outside Kalimantan. Another challenge is children's interest in learning the Paser language. The delivery of spoken and written language material by teachers so far is still not effective in increasing students' interest and enthusiasm for learning. So, there is a need for supporting media for teaching the Paser language to deliver learning materials that can arouse students' interest in learning the Paser language.

Digital-based learning media are becoming very popular, especially during the COVID-19 pandemic. Digital learning media is considered able to improve learning outcomes because it can convey learning material better than verbal methods in oral and written form. Digital learning media is a device that can convey material adequately [5]. It has many advantages, for instance, it can convey material in the form of visual animation, video, and sound simultaneously. Conventional learning media require tools as props that describe an object while digital learning media can be in the form of mobile applications that can directly display shapes, sounds, and visual images simultaneously.

The results of research conducted Aziz Ardiyansah [6] regarding the role of mobile learning in improving learning outcomes. It is believed that digital media can increase student participation so that learning is more effective. Moreover, digitalbased learning media can improve student learning outcomes with the direct involvement of users in learning. Digital-based learning media stimulates users with visual animations, sounds, and variants of elemental forms. Humans can interpret an object called semiosis, this is an ability that is possessed since birth [7].

In addition, digital learning media can provide stimulation to users, because basically, humans have strong senses, for example, if a hand is hit by fire, the brain will reflexively give orders to the hand to move away from the fire. In the end, the digital application learning method will be much more interesting, and the audience can have a better experience in learning engagement.

\subsection{Research Purpose}

The purpose of this article is to find out the potential for developing digital applications as language learning media from the visual aspect of the application and the application flow. The author provides a comparison of the results of testing three digital language applications that affect children's interest and understanding of the material provided and the relationship between the three applications.

\section{METHOD}

In this article, the author uses qualitative methods to understand the visuals and flow of digital media. Qualitative research deals with human behavior and describes the challenges faced in language teaching. Researchers want to see the potential need for digital applications as a medium for learning the Paser language. Creswell [7] claims that qualitative data presented is based on scientific papers, published research results, and documentation. The author also uses an audio-visual comparison method on three applications that have been tested to see visual applications that children like by involving users [9].

\subsection{Mc Carthy Method}

In digital applications, the visual display is the main point, the visual display or user interface abbreviated as UI is a graphical display that serves as a direct link between the user and the application or web media so that the system can run properly and the application can be used [11]. In Léon McCarthy's research (2016), his dissertation discusses how visual and flow apps can involve users so that they can enter and interact with these digital media. The following is the research method of Léon McCarthy [9].

\section{Method I}

The main strategy is that the viewer is given a video view and the viewer only watches the show from start to finish. The audience's reaction to the trial with the initial method looks inactive and flat. This happens because the audience can hardly be directly involved with what is presented.

\section{Method II}

In the next technique, the audience is presented with audio-visual shows and towards the end of the show. The audience is given time to express their opinions and provide criticism or suggestions on the shows they have just seen. In this trial using the second method, the audience seemed more satisfied, because they felt more interacted with the shows they watched.

\section{Method III}

In the third strategy, the audience is directly involved in real-time in creating the impression that the visual media displayed appears or appears to be real. In this strategy, the audience has a contribution 
of 'logical circumstances and results' as recently explained in Chion's hypothesis in McCarthy (2016) that the contribution of the audience will directly affect the results (visual media presented). Even in a situation like this, the media producers also continue to coordinate the course of the audience's thoughts so that they are as comfortable as possible within the limits that have been set.

\section{Method IV}

The fourth technique is to introduce makers, crowds, and specialists to research the impressions that have been viewed. In the fourth test, the audience was effectively elaborated verbally like a conversation with an expert. For these situations, the specialist's ability to assess and coordinate the course of the conversation so that the conversation remains enjoyable and on point. Audience inclusion in this strategy is more emphasized on verbal contributions compared to experiences in using audio-visual media. For these situations, it tends to appear that constant collaboration essentially extends audience engagement collaboration. For the third and fourth trials, the audience was effectively engaged with visual media impressions. With a low level of attention, it will indirectly move the audience to better understand the shows they watch, the visual images they see, and the sounds they hear. The same thing will also happen to the learning media commonly used by students. Digital media as learning media does not only function as a tool in conveying material, but also has a role in expanding student interaction in learning.

\section{THD DATA}

\subsection{Field Research Data}

Researchers conducted a field survey on February 12, 2021, at the 011 State Elementary School, Longkali District, Paser Regency which will be the object of research. Researchers conducted unstructured interviews which aimed to measure students' readiness to use technology as a media to support paser language learning and to determine the socio-cultural conditions of the community. The results of interviews with schools and teaching teachers said that students were familiar with smartphones before entering elementary school. Then it was strengthened by the results of interviews with parents who said that they had allowed their children to use smartphones to play games or watch their favorite cartoons since kindergarten. To see how much digital technology is used, it is explained from the survey results of the Statistical Information Communication Service of Paser Regency (2021) [29]. The survey results show that the use of technology and internet access in the Paser area has a good presentation of network access with (97\%) having an internet connection and the remaining 3\% are still in the development stage of digital touch.

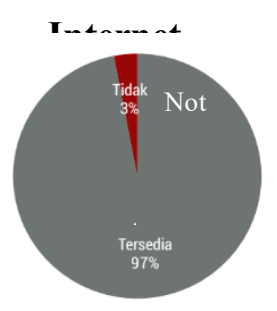

(a)

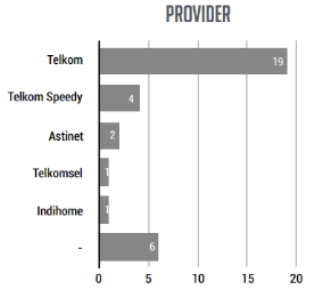

(b)
Figure 1. (a) Internet availability, (b) Provider. Source: https://jdih.paserkab.go.id

\subsection{Field Research Data}

The study uses several data. First, the digital illustration book of folklore for learning the introduction of Paser language by Tri Bayu S [12]. Digital-based visual media in the form of animation as an active student learning method by Neng Marlina E [13] and educational games for learning English by improving the cognitive abilities of early childhood Fifi Nur A [14]. Of the three visual media selected as a comparison between educational media, researchers tried to collaborate between media, especially in the selection of visual images, such as in the study of Tri Bayu S who introduced Paser language through folklore books whose contents were very close to the socio-cultural conditions of the local Paser community. The following are the results of research from the 3 media.

\section{Media I, digital illustration book (Tri Bayu S)}

In a study conducted by Tri Bayu S, he used a digital illustration book entitled "The Story of the People of Pego and Putri Kayangan" as a medium for recognizing the Paser language which was tested for elementary school students to high school students aged 7-18 years. Tri Bayu $\mathrm{S}$ used a short video containing the contents of the book with a visual style displayed according to the contents of the book. Then, the students were asked to watch a short video that lasted about 5 minutes. Next, students are asked to write down important messages in the folklore. After that, multiple-choice questions were given as an evaluation to see students understanding of the message conveyed in the story. Tri Bayu S employed 
Johnston's story video media as the main strategy that, the audience is given general media impressions without any interaction made by the audience with the media.

\section{Media II, Animation (Neng Marlina E.)}

In a study conducted by Neng Marlina E, he analyzed the use of digital animation on various educational start-ups such as Ruang Guru, Zenius, and Quipper. In the experiment, students were asked to listen to animated videos taken from the three startups, each with a duration of approximately 5 minutes. Then, they were asked to make a note the important things from each animated video. Also, the student, got some evaluation questions related to the video measuring students' understanding of the message conveyed. This method is similar to McCarthy's second method [9] that students are allowed to be able to listen and record important things from animated video shows.

\section{Media III, Educational Game (Fifi Nur A)}

In the third experiment, educational games media is utilized to improve preschool children's cognition in the introduction of English by using English Games. English Games is a learning method by playing but still includes learning, so it is not boring [15]. English Games are designed to make children can think cognitively through interactive media games. It is stimulated by guessing words, guessing colors, guessing letters/alphabets, guessing numbers, guessing pictures, guessing fruit names, guessing names of body parts, and so on. Visual appearance on educational games media is the key to success in increasing student attractiveness. This trial is like McCarthy's 3rd method [9] that participants or students can be directly involved with the audiovisual media used.

\section{RESULTS}

The three digital visual media as mention earlier was tried on various ages and backgrounds of the audience. They showed different results. One of important results is, the three media could build deeper audience interest and involvement regarding the material introduced. This is also supported by the hypothesis which states that the use of visual media in learning can expand audience interactions, both tangible and intangible, such as beneficial experiences or quality of life [16].

The first study (Tri Bayu S) used a digital book of Paser folklore that was introduced through a narrative video to elementary school and high school students. The results showedo that graphic visual analysis, modeling of characters or characters, settings, and storylines are very influential on student interest so that overall students understand what is conveyed in the narrative story. In contrast, the students who are given the same folklore without any visuals do not understanding the content of the story. Although the results are not so significant (Tri Bayu S). This study give mean that the presence of visual images greatly affects the results of student understanding than ordinary textbooks.

The use of video media to tell stories is seen as an effort to pass on the value and validity of a situation and make the audience connect with the video presented. It provides a different learning experience. From this interesting experience, students can take certain messages and feel satisfied with the learning provided.

The digital book learning media which is then promoted in the form of videos is more organized and is included in the I McCarthy method, where groups of people only see what shows are presented as learning media, but are not directly connected to it. From the result of this beginning, McCarthy's strategy and Johnston's test seem, to be directly compared with each other. However, there is still a lack of audiences who cannot interact actively. Learning using media like this can only affect the material presented at a very basic level. Based on related references, it can be seen that the consideration of making digital storybooks was carried out with students from various age groups, instructors, or teacher educators [17]. It has been seen that creating digital stories can give a deeper experience to the student.

In the 2nd trial conducted by Neng Marlina E, the animation from various start-up platforms such as Ruang Guru, Zenius, and Quipper was taken to see what kind of animation students liked and give significant impact on children's understanding. The result showed children prefer animation that is rich in color. In addition, characters, storylines, and plots can significantly give contribution to students' understanding., these parts are important because students' understanding can be seen if it can retell a certain part although it is not specific.

In addition, as an animation evaluation, the teacher provided additional explanations about the messages conveyed from the animated videos after they watched. These values are a description of the animated characters and the plot of the story. From the visual animation, students are indirectly invited to 
enter the story, so that involvement is also built up unconsciously.

Online instructive assets, for example, activities are increasingly being used in clinical practice to assist patient-physician associations, especially when the advice affects children. Young people are regularly referred to as 'computerized locals' because of the ubiquity of innovation in their daily lives. In 2016 , 98\% of young people and youth in the UK approached the web, $83 \%$ of 12-to 15 -year-olds had their own mobile phone and $55 \%$ had their own tablet [18]. In matters related to McCarthy's second method, many participants felt involved and aware in learning by writing down the important parts contained in the video. The development of audience involvement in learning from animated video media increases audience engagement and results in better understanding than previous learning techniques.

In the last trial conducted by Fifi Nur A, educational English games, called English Games was utilized to deliver educational material. Through games, the material can be wider and very interactive, and fun. It is because the concept of educational games is playing and learning. Children like something imaginative, art, and coloring" [19]. Children should be given the treatment of learning English Games with a game such as cards, reading fairy tales, singing, coloring pictures, guessing, and completing pictures (puzzles) to train children's intellectual abilities. It can also make children gradually improve their listening, speaking, syntactic, reading, writing skills and can further develop their thinking, intuition, and innovative patterns with fun and effective learning [15]. Learning with play strategies is considered very appropriate for the learning of adolescents or children in the preschool time frame. Because by playing, children can think well without support or intimidation which will make them awkward in learning [20].

Instructive games have been utilized to show content in different subjects, for example, science [21], arithmetic, and physical science [22], just as exploration on natural frameworks [23]. what's more, have been displayed to study and further foster understudies' non-scholarly capacities like innovativeness (e,g, Blanco-Herrera, Gentile, and Rokkum, Shute and Rahimi), and eager (e,g, BlancoHerrera, Gentile, and Rokkum) [24-25]. These and other tests are considered positive, but further exploration is needed. The use of educational games in learning media is identified with the third strategy carried out by McCarthy (2016). Computer-generated educational games allow clients to work directly and progressively with the media and are effectively linked to learning exercises. With this computergenerated simulation media, it will positively expand the interest, inspiration, and contribution of many people in learning.

\section{DISCUSSION}

Based on the description above, there are several findings from the results of the trial of the three digital-based learning media which are dominated by visual displays as the center of attention in increasing student interest and motivation.

\section{Visual Media Digital Illustration Book}

In the digital illustration book media, which is promoted in the form of a narrative video to facilitate the research process during the Covid-19 era, researchers send videos containing book content, all forms of storylines, characters, figures, visual displays, and so on, conceptualized according to the book "Stories of the People of Pego and Putri Kayangan" which aims as a medium for introducing Paser language to elementary and junior high school students. The narrative videos stimulate to make students involve from the emotional point of view. Emotional involvement depends on how to package a story and spice it up as visually as possible., If it is not interesting then the impact received by the audience is not significant on the audience's understanding of the material presented. However, when compared to children's storybooks, which are generally printed in a textbook and accompanied by several pictures, children still cannot understand without an explanation from the teacher or parent.

Animated visual media

Audiences are involved more towards a different experience from each existing animation because each animation has its style in terms of form, storyline, and visual character. Animations are made to reflect the forms of experience that have been seen and received before. From this perspective, many audiences find it easier to understand the messages and stories presented. An understanding that concentrates on learning media in the form of visual animation is more easily accepted by students compared to formal learning that is conveyed verbally, which is more difficult for students to understand.

Media Visual Games Education 
Game learning media is quite widely used for various subjects such as mathematics, physics, science, English, and regional languages. As well the previous research conducted by Astari, T.Y., Rasmani, U. E. E., \& Dewi, N. K. (2020), this study focuses on English subjects with games methods such as flashcards, word-setting games, and singing. Another research by Adimayanti, E., \& Siyamti, D. (2020) uses the English language as therapy by using games through guessing pictures, guessing words, guessing colors, and so on. In the game learning media, students can be fully involved directly. The involvement that is built in the form of emotions and physical can be an interesting experience for children. Moreover, it is packaged with full-color visuals and funny characters making this educational game even more interesting.

The use of educational games can stimulate a more interesting learning process. It is very possible to stimulate users to feel more emotions. Every audience will feel different emotions and can increase audience engagement. Through games, users will be taken to a different world in the form of virtual games. Therefore, the use of educational games technology has a fairly good effect on increasing student engagement, motivation, and learning outcomes.

\section{CONCLUSION}

The use of educational games can stimulate a more interesting learning process and it is possible to stimulate users to feel more emotions. Every audience will feel different emotions and that is what it is built to increase audience engagement. Through the game, users will be taken to a different world in the form of virtual games. Therefore, the use of educational game technology has a fairly good effect on increasing student engagement, motivation, and learning outcomes

The essence of this digital learning media is how to build an attractive visual display so that it can be accepted and liked by the audience. In the process, the use of digital builds many things, such as new and emotional experiences, the more involvement of the audience in media, the better the acceptance of the audience's understanding of the material provided.

Three digital media that have been tested on students have their advantages depending on the selected target user. However, if we look at the dominant audience involvement, the educational games media have the most potential to improve learning outcomes. From the results of the same study, educational games are proven to improve student learning outcomes. This is influenced by the direct interaction that can be obtained when this educational game is played by the user. These interactions produce the player's emotions and have a physical effect so that the resulting experience is different.

The final conclusion, is the used of digital medium for learning the local language of the Paser ethnic, will have the potential with a high success rate. Making digital media in the form of language learning applications must contain several important things that have been summarized based on the results of testing the three applications described above. The important thing to note is that the application that is made must concern the visual appearance because as an initial trigger of audience interest. In addition, the application should contain games designed according to the needs of the audience. Overall, in-app games create active interactions that affect learning success. Then the researcher will approach the introduction of paser language through applications with memory games such as stringing words, guessing pictures, and guessing sounds, adding approaches to shapes, colors, patterns, and characters according to the local culture of the paser tribe.

\section{ACKNOWLEDGMENTS}

Through this statement the author would like to thank the supervisor Dr. Intan Rizky Mutiaz, M.Ds. who has assisted the author in completing the article in the Atlantis Press Journal.

\section{REFERENCES}

[1] M. Choirudin, I.I. Ratnawati, Nilai Budaya Dalam Buku Cerita Rakyat Paser dan Berau, in : Jurnal Basataka, vol.1(1), pp.45-57, 2018. https://jurnal.pbsi.uniba-bpn.ac.id

[2] Abd. Kadir Sambolangi, 2020. Bahasa Paser Jangan Punah, https://paserkab.go.id/berita/humas/bahasapaser-jangan-punah-please

[3] N. Fitri, Hartini. (2020). Meningkatkan Kemampuan Berbicara Bahasa Inggris Melalui Strategi Bermain Aktif Pada Anak TK B Aisyiah Bustanul Athfal 1 Denpasar Tahun 2016, in : Jurnal Sakinah : Journal of Islamic and Social Studies, vol.2(1), pp.37-46, 2020. 
[4] H. Abdul Gafur Mas'ud. 2020 Peduli Kearifan Lokal-Bupati Wajibkan Mulok Bahasa Paser Disekolah, https://penajamkab.go.id/?p=588

[5] Suryantoro, Penggunaan Audio Visual untuk Peningkatan Keterampilan Menyimak Dongeng Siswa SMP Negeri 2 Pakisaji Malang, in : Jurnal Inspirasi Pendidikan, vol.5(1), pp.560567, 2015.https://doi.org/10.21067/jip.v5i1.686.

[6] Aziz Ardiyansah. 2020. Peran Mobile Learning sebagai Inovasi dalam Meningkatkan Hasil Belajar Siswa pada Pembelajaran di Sekolah, https://ejournal.undiksha.ac.id/index.php/IJERR /article/view/24245

[7] K.B. Jensen, 2015. Semiotics. International Encyclopedia of the Social \& Behavioral Sciences (Second Edition), edited by James D. Wright, 592-597Elsevier. https://doi.org/10.1016/B978-0-08-0970868.95033-5.

[8] J.W. Creswell, 2012. Educational research. ( 4th Ed). Boston: Pearson. https://www.scirp.org/(S(351jmbntvnsit1aadkpo $\underline{\text { szje)}) / \text { reference/ReferencesPapers.aspx?Referen }}$ ceID $=757162$

[9] L. McCarthy, 2016, Steering Audience Engagement During Audio-Visual Performance. Doctoral Dissertation, Northumbria University. http://nrl.northumbria.ac.uk/31605/.

[10] Lv Zhihan, Xiaoming Li, and Wenbin $\mathrm{Li}$, Virtual reality geographical interactive scene semantics research for immersive geography learning, in : Neurocomputing, vol.254, pp.7178 , 2017. https://doi.org/10.1016/j.neucom.2016.07.078.

[11] D. Fackhruddin, et al., Pengembangan Desain Informasi dan Pembelajaran Aksara Jawa Melalui Media Website. In : ANDHARUPA: Jurnal Desain Komunikasi Visual \& Multimedia, vol. 5,(1), pp. 1-23, 2019. doi:https://doi.org/10.33633/andharupa.v5i01.19 90.

[12] L. McCarthy. Steering Audience Engagement During Audio-Visual Performance. Doctoral Dissertation, Northumbria University, January 2016. http://nrl.northumbria.ac.uk/31605/.

[13] T.B. Saputra. Perancangan Buku Ilustrasi Cerita Rakyat Pego dan Putri Kayangan Sebagai Media Belajar Bahasa Paser. Thesis, Institut Seni
Indonesia, $\quad$ Yogyakarta, 2021. http://digilib.isi.ac.id/7766/10/Tri\%20Bayu\%20 Saputra 2021 NASKAH\%20PUBLIKASI.pdf

[14] N.E. Efendi, Revolusi Pembelajaran Berbasis Digital (Penggunaan Animasi Digital Pada Start Up Sebagai Metode Pembelajaran Siswa Belajar Aktif), in : Habitus: Jurnal Pendidikan, Sosiologi, \& Antropologi, vol.2(2), 2018. https://jurnal.uns.ac.id/habitus/article/view/2878 8

[15] F.N. Afifa, S. Gumiandari, Implementasi English Game Dalam Meningkatkan Kemampuan Kognitif Anak Prasekolah Di Usia Dini, in : Yaa Bunayya : Jurnal Pendidikan Anak Usia Dini, vol.5(1), 2021. https://jurnal.umj.ac.id/index.php/YaaBunayya/a rticle/view/7858/5552

[16] E. Adimayanti, D. Siyamti, D, Terapi Bermain English Game Untuk Meningkatkan Kemampuan Kognitif Anak Prasekolah, in: Jurnal Pengabdi Kesehatan, vol.3(2), pp.115$122,2020$.

[17] Lv Zhihan, Xiaoming Li, and Wenbin $\mathrm{Li}$, Virtual reality geographical interactive scene semantics research for immersive geography learning, in : Neurocomputing, vol.254, pp.7178 , 2017. https://doi.org/10.1016/j.neucom.2016.07.078.

[18] Dong-Hee, Shin, The role of affordance in the experience of virtual reality learning : Technological and affective affordances in virtual reality, in : Telematics and Informatics, vol.34(8), pp. 1826-1836, 2017. https://doi.org/10.1016/j.tele.2017.05.013.

[19] B.R. Robin, et al., The educational uses of digital storytelling, C. Crawford (Ed.), in : Proceedings of Society for Information Technology \& Teacher Education International Conference 2006, Chesapeake, VA: AACE, 2006, pp. $709-716$ ViewRecordinScopushttps://www.scopus.com/r ecord/display.uri?eid=2s2.078049375613\&origi $\underline{\mathrm{n}=\text { inward\&txGid }=3 \mathrm{~d} 054 \mathrm{ba} 964132 \mathrm{a} 6 \mathrm{~d} 4733 \mathrm{eb} 18}$ b37d4ea6

[10] M.F. Ciğerci İlkokul 4.sınıf Türkçe dersinde dinleme becerilerinin geliştirilmesinde dijital hikayelerin kullanımı. (Unpublished $\mathrm{PhD}$ thesis) Anadolu University, Eskişehir, 2015. 
[11].B. Dinçer and İzmir (2019) Dijital hikaye temelli matematik öğretiminin ortaokul öğrencilerinin kavram öğrrenmeleri üzerine etkileri. (Unpublished master's thesis) Dokuz Eylül University, Google Scholar

[12].S. Ulusoy Dijital hikaye destekli örnek olaya dayalı öğrenme ortamlarının fen öğrenme üzerindeki etkileri. (Unpublished master's thesis) Uşak University, Uşak (2019) Google Scholar

[14] G. Özüdoğru, H. Çakır, An investigation into the opinions of pre-service teachers toward uses of digital storytelling in literacy education, in : Participatory Educational Research (PER), vol.7(1), pp.242-256, 2020. CrossRefView Record in ScopusGoogle Scholar

[15] J. Wu, D.T. Chen, A systematic review of educational digital storytelling, in : Computers \& Education, vol.147, 2020. 10.1016/j.compedu.2019.103786 Google Scholar

[16] A. Kapoor, W. Burleson, R.W. Picard, Automatic prediction of frustration, in : International Journal of Human-Computer Studies, vol. 65(8), pp.724-736, 2007. 10.1016/j.ijhcs.2007.02.003 Article Download PDFView Record in Scopus Google Scholar

[17]J. Hamari, D.J. Shernoff, E. Rowe, B. Coller, J. Asbell-Clarke, T. Edwards, Challenging games help students learn: An empirical study on engagement, flow and immersion in gamebased learning, in : Computers in Human Behavior, vol.54, pp. 170-179, $2016 . \quad$ 10.1016/j.chb.2015.07.045 ArticleDownload PDFView Record in $\underline{\text { ScopusGoogle Scholar }}$

[18] M.L. Biles, J.L. Plass, B.D., Homer, Designing digital badges for educational games: The impact of badge type on student motivation and learning, in : Learning and performance assessment: Concepts, methodologies, tools, and applications, IGI Global, pp. 1349-1369, 2020. CrossRefView Record in ScopusGoogle Scholar Boyle et al., 2016

[19] J.M. Keller Motivation and instructional design: A theoretical perspective, in : Journal of Instructional Development, pp. 26-34, 1979. View Record in ScopusGoogle Scholar
[20] J.M. Keller Motivational design for learning and performance: The ARCS model approach Springer Science \& Business Media, 2009. Google Scholar

[21] Hidayati, et al., Meningkatkan Kosa Kata Bahasa Inggris Anak Usia Dini Dengan Kartu Bergambar, in : Indonesian Journal Of Early Chilhood Islamic Education. 1(1), pp.67-86, 2017.

[22] E. Adimayanti, D. Siyamti, D, Terapi Bermain English Game Untuk Meningkatkan Kemampuan Kognitif Anak Prasekolah, in: Jurnal Pengabdi Kesehatan, vol.3(2), pp.115$122,2020$.

[23] V.J. Shute, F. Ke Games, learning, and assessment, D. Ifenthaler, D. Eseryel, X. Ge (Eds.), Assessm ent in game-based learning: Foundations, innovations, and perspectives, Springer, New York, NY (2012), pp. 43-58 CrossRefView Record in ScopusGoogle Scholar

[24] V.J. Shute, S. Rahimi, Stealth assessment of creativity in a physics video game, in : Computers in Human Behavior, vol.116, pp. 113, 2021. 10.1016/j.chb.2020.106647 View Record in ScopusGoogle Scholar Shute et al., 2020

[25].V.J. Shute, S. Rahimi, G. Smith, F. Ke, R. Almo nd, C.-P. Dai, C. Sun Maximizing learning without sacrificing the fun: Stealth assessment, adaptivity, and learning supports in educational games, in : Journal of Computer-Assisted Learning, pp. 1-15, 2020.10.1111/jcal.12473 View Record in ScopusGoogle Scholar Spann et al., 2019

[26].C.A. Spann, V.J. Shute, S. Rahimi, S.K. D’Mell $\mathrm{o}$, The productive role of cognitive reappraisal in regulating affect during game-based learning, in : Computers in Human Behavior, 100, pp.358-369, 2019. 10.1016/j.chb.2019.03.002 ArticleDownload PDFView Record in ScopusGoogle Scholar Shute, 2011

[27] Blanco-Herrera, Gentile, dan Rokkum, 2019, How to increase learning while not decreasing the fun in educational games, R. Feldman (Ed.), Learning Science: Theory, Research, and Practice, McGraw Hill, New York, NY (2019), pp. 327-357 View Record in ScopusGoogle Scholar 
[28] T.T. Astari, U.E.E. Rasmani, N.K. Dewi, Pelaksanaan Pembelajaran Bahasa Inggris Anak Usia Dini, in : Jurnal Kumara Cendekia, vol.8(2), pp.196-210, 2020.

[29]. Masterplan E-Government - JDIH Kab. Paser Kabupaten Paser (2018-2022) jdih.paserkab.go.id 5 september 2021 https://jdih.paserkab.go.id/assets/library/docume nt/perbup-nomor-8-tentang-penyelenggaraan-egovernment-di-lingkungan-pemerintahkabupaten-paser.pdf 